\title{
Analisis Nilai Tambah pada Usaha Se'i Sapi di Kota Kupang Provinsi Nusa Tenggara Timur
}

\author{
Fransiskus Yulius Dhewa Kadju ${ }^{a^{*}}$, Budi Hartono ${ }^{b}$, Bambang Ali Nugrohob \\ a Fakultas Pertanian, Universitas Timor, Kefamenanu, TTU - NTT, Indonesia \\ ${ }^{b}$ Fakultas Peternakan, Universitas Brawijaya, Malang, Jawa Timur, Indonesia
}

*Corresponding author: fransiskuskadju@unimor.ac.id

\section{Article Info}

\section{Article history:}

Received 14 April 2021

Received in revised from 18 April 2021

Accepted 24 June 2021

DOI:

https://doi.org/10.32938/ag.v6i3.1360

Keywords:

Beef

Value-added

Se'I cow meat

\begin{abstract}
Abstrak
The high added value of beef agro-industry has increased competition among business actors, both for marketing processed products and for obtaining raw materials. The calculation of the added value of marketing se'i cow meat in Kupang City is the main objective of this research. The research was carried out during June - July 2019. The survey method was the method used during this research. Determination of the sample in this study using purposive sampling technique with five examples of MSME respondents. The results of calculations using the Hayami Method obtained an added value of Rp. 18,804.73 for each se'i product sold.
\end{abstract}

\section{Pendahuluan}

Subsektor peternakan telah menjadi bagian tak terpisahkan dari pembangunan perekonomian di Indonesia; terkhususnya bagi pembangunan sektor pertanian. Peranan penting sektor pertanian dapat dilihat melalui andilnya dalam menentukan pendapatan negara, pembentukan pendapatan daerah, serta peningkatan jumlah pekerja pada sektor pertanian. Selain itu, penyiapan bahan baku industri hingga pada pemenuhan produk yang dikonsumsi penduduk merupakan peranan penting dari sektor pertanian. Konsumsi daging sapi oleh penduduk Indonesia diperkirakan mencapai $2,40 \mathrm{~kg} / \mathrm{kapita} /$ tahun pada tahun 2017; meningkat 3,85\% dibandingkan pada tahun 2016. Populasi ternak sapi juga meningkat menjadi 16,60 juta ekor pada tahun 2017; meningkat menjadi 3,72\% dibandingkan pada tahun 2016 (Pusat Data dan Sistem Informasi Pertanian, 2017).

Pemenuhan nutrisi masyarakat di Indonesia dapat ditingkatkan dengan memanfaatkan sumber daya alam sektor peternakan yang berujung pula pada peningkatan PDB negara. Pemenuhan nutrisi tersebut dapat dipengaruhi oleh beberapa faktor, diantaranya permintaan bahan pangan hewani yang semakin meningkat, bertambahnya jumlah penduduk, serta perubahan pola konsumsi masyarakat pada produk bergizi tinggi. Salah satu upaya yang dapat dilakukan untuk memenuhi nutrisi masyarakat adalah mengkonsumsi pangan asal hewani; produk yang berasal dari ternak sapi potong.

Kota Kupang merupakan ibukota Provinsi Nusa Tenggara Timur dan merupakan salah satu kota terbesar yang berada di Pulau Timor. Kota Kupang sendiri merupakan tempat berkembangnya perusahaan-perusahaan pengolahan pangan yang mendukung perekonomian daerah; khususnya perusahaan yang bergelut dengan produk-produk asal daging sapi. Produk asal daging sapi seperti abon, dendeng, dan se'i; merupakan produk yang menjadi ciri khas Kota Kupang dan banyak diproduksi oleh masyarakat. NTT merupakan salah satu daerah penghasil ternak sapi potong di Indonesia dan memperoleh peringkat 5 nasional selama beberapa tahun berturut-turut, yaitu dari tahun 2016 hingga tahun 2018. Pada jangka waktu dan urutan yang sama, kelima provinsi penyumbang terbanyak sapi potong di Indonesia berturut-turut adalah Provinsi Jawa Timur, Jawa Tengah, Sulawesi Selatan, Nusa Tenggara Barat, dan Nusa Tenggara Timur (Badan Pusat Statistik Indonesia, 2018). Sumbangan ternak sapi asal NTT pada tahun 2016 mencapai 984.551 ekor, 1.007.608 ekor pada tahun 2017, dan 1.027.286 ekor pada tahun 2018. Selanjutnya, data BPS menunjukkan bahwa jumlah industri pengolahan makanan di Kota Kupang sebanyak 343 perusahaan. Oleh karena itu, industri pengolahan daging sapi memiliki peluang untuk bersaing memenuhi permintaan konsumen dilihat dengan banyaknya jumlah perusahaan pengolahan makanan di Kota Kupang (Badan Pusat Statistik Provinsi Nusa Tenggara Timur, 2018).

Permintaan daging sapi di Kota Kupang berdasarkan data BPS melebihi jumlah ternak yang tersedia di wilayah Kota Kupang. Rumah Potong Hewan (RPH) Kota Kupang pada tahun 2017 telah menjagal ternak sapi sejumlah 12.739 ekor, sedangkan pada tahun yang sama Kota Kupang hanya menghasilkan tenak sapi dengan jumlah 6.202 ekor. Penyebab jumlah pemotongan ternak lebih tinggi dibandingkan jumlah ternak yang dihasilkan diindikasikan karena ternak sapi yang dipotong kebanyakan berasal dari daerah di luar Kota Kupang. Hal ini dapat dilihat dari jumlah kontribusi sapi potong dari ketiga kabupaten lainnya yang berada dalam kawasan Pulau Timor, yaitu dari Kabupaten Kupang sebanyak 221.380 ekor, Kabupaten Timor Tengah Selatan sebanyak 190.683 ekor, dan Kabupaten Timor Tengah Utara sebanyak 122.771 ekor (Badan Pusat Statistik Kota 
Kupang, 2018). Usaha pemasaran daging sapi merupakan usaha potensial yang berpeluang besar dalam meningkatkan pendapatan daerah Kota Kupang.

Usaha industri daging sapi berperan dalam menyediakan sumber nutrisi; khususnya sumber protein bagi masyarakat. Tingkat permintaan daging sapi yang cenderung naik dari tahun ke tahun menunjukkan terdapat beberapa faktor penting yang meningkatkan konsumsi masyarakat, diantaranya kemudahan untuk memperoleh produk daging sapi, pengetahuan masyarakat yang semakin meningkat akan konsumsi pangan sumber protein, peningkatan pada usaha penjualan makanan yang menyajikan daging sapi sebagai salah satu produknya, semakin bertambahnya pendapatan yang diperoleh masyarakat, dan besarnya minat masyarakat pada produk daging sapi. Pertumbuhan jenis usaha yang memproduksi pangan yang berasal dari daging sapi juga dapat diketahui melalui penambahan jumlah ternak sapi potong di Indonesia. Secara nasional, produksi daging sapi meningkat dengan rata-rata persentase kenaikan setiap tahun sebesar $1,74 \%$. Kenaikan rata-rata produksi tersebut turut dipengaruhi oleh peningkatan produksi daging sapi setiap tahunnya. Sebagai contoh, produksi daging sapi nasional pada tahun 2018 mencapai 497.971,70 ton; meningkat dibandingkan tahun 2017 dengan total produksi sebesar 486.319,65 ton (Badan Pusat Statistik Indonesia, 2018).

Kusnandar et al., (2010) dan Marsudi (2013) mengemukakan bahwa agroindustri merupakan suatu industri yang menggunakan hasil pertanian sebagai bahan baku utama. Agroindustri merupakan badan atau perusahaan pengolahan bahan baku asal tumbuhan atau hewan yang memproses bahan baku tersebut menjadi produk yang berdaya guna. Proses untuk menghasilkan produk agroindustri meliputi beberapa tahap, yaitu proses pengolahan serta pengawetan yang bisa dilakukan secara fisik atau secara kimiawi, proses penyimpanan, dan proses pengawasan dari produksi hingga pengiriman produk sehingga dapat meningkatkan nilai tambah, produksi, serta produk yang kualitasnya telah ditingkatkan. Agroindustri berpotensi besar untuk terus berkembang karena persaingan pasar bagi produk di sektor ini belum terlalu ketat. Selanjutnya, Pasaribu (2012) juga menambahkan agroindustri sebagai industri berbasis sumber daya yang berpotensi meningkatkan cadangan devisa serta penyediaan lapangan kerja.

Adanya proses pengolahan terhadap input tertentu dalam produksi merupakan konsep awal yang membentuk teori nilai tambah. Aspek nilai tambah dapat dilihat melalui dua pendekatan, yaitu secara kuantitatif dan kualitatif. Aspek kuantitatif nilai tambah dilihat dari peningkatan produksi suatu perusahaan. Selanjutnya, aspek kualitatif diperoleh dengan menilai peningkatan pengetahuan pekerja, adanya peluang untuk memperoleh pekerjaan, serta kemampuan yang dimiliki pekerja dalam melaksanakan tugas yang dipercayakan padanya. Industri atau perusahaan pengolahan merupakan sektor hilir dari suatu usaha pertanian dan merupakan wilayah tempat dimana kerap terciptanya nilai tambah pada suatu produk. Sifat mudah rusak dan membutuhkan tempat yang cukup luas untuk penyimpanannya menyebabkan komoditas hasil pertanian memerlukan perlakuan tertentu sebelum nantinya siap dikonsumsi konsumen. Perlakuan pada komoditas pertanian meliputi proses pengolahan, pengawetan, pengemasan, serta jaminan mutu sehingga meningkatkan nilai tambah dan harga produk (Marimin dan Maghfiroh, 2010).

Produk pangan hewani yang biasa dikonsumsi masyarakat biasanya merupakan produk segar ataupun olahan asal ternak sapi, babi, ayam, maupun hasil laut lainnya seperti ikan. Keunggulan produk daging sapi segar dibandingkan produk pangan hewani lainnya adalah kandungan gizi pada daging sapi cukup tinggi. Daging sapi yang telah diolah menjadi sebuah produk juga cenderung memiliki kalori produk dua kali lipat lebih tinggi dibandingkan dengan daging sapi yang belum diolah (Soeparno, 2005). Harga produk-produk pangan hewani cenderung bervariasi sehingga turut mempengaruhi minat dan permintaan produk-produk tersebut di pasaran. Di Kota Kupang, harga daging sapi segar dan produk olahannya (seperti abon dan dendeng) dipengaruhi oleh variasi harga pada masing-masing saluran pemasaran mulai dari penjualan ternak sapi di tingkat petani hingga pemasaran dagingnya di RPH (Noach \& Lalus, 2020; Kadju et al., 2020a).

Se'i merupakan produk olahan daging populer yang diproduksi dan dikonsumsi oleh penduduk NTT. Saat ini, masyarakat Pulau Timor dan Pulau Rote merupakan konsumen terbesar yang mengkonsumsi produk se'i. Untuk mempertahankan kualitas dan cita rasa daging, proses produksi se’i menggunakan pengasapan. Bahan mentah se’i diambil dari daging sapi segar kemudian diolah dengan menambahkan bumbu-bumbu lainnya. Se'i sapi memiliki daya simpan minimal 4 hari di suhu ruang dan maksimal hingga 4 minggu jika disimpan secara vakum (Suluh, 2019).

Sebagai salah satu produk dari usaha pengolahan hasil peternakan; se'i diolah pengusaha dan merupakan bagian dari industri hilir usaha peternakan sapi potong. Selain untuk memenuhi kebutuhan nutrisi masyarakat, tujuan lain pembuatan se'i adalah sebagai cara untuk menganekaragamkan produk hasil pengolahan daging sapi yang juga turut mempengaruhi lama simpan produk tersebut. 
Bagi pengusaha, tujuan utama dari suatu usaha agroindustri adalah untuk memperoleh keuntungan optimal dari besaran input tertentu sehingga usaha tersebut dapat berkembang dan siklus hidupnya dapat dipertahankan. Pengukuran biaya produksi; terutama analisis nilai tambah, merupakan hal penting yang melandasi siklus produksi yang berkelanjutan dalam suatu perusahaan. Penelitian ini dilaksanakan untuk menganalisis nilai tambah usaha se’ $i$ sapi di Kota Kupang.

\section{Metode}

Waktu pelaksanaan penelitian dilakukan sejak bulan Juni hingga bulan Juli 2019 di wilayah Kota Kupang, Provinsi NTT. Awal penelitian dilakukan dengan menyusuri swalayan dan minimarket di seputaran Kota Kupang untuk melihat UMKM mana saja yang secara kontinu memasok produk se'i. Penelitian dilanjutkan dengan menelusuri tempat para pelaku usaha memproduksi produk se'i-nya. Pemilihan perusahaan agroindustri yang dijadikan sampel penelitian ditentukan melalui beberapa syarat, diantaranya perusahaan memproduksi se'i sapi, pernah menjual se'i sapi dalam satu tahun terakhir, produk se'i dijual secara reguler dan masih beredar di pasaran, serta menghasilkan produk se'i secara berkelanjutan. Berdasarkan kriteria penilaian; terpilih beberapa perusahaan agroindustri yaitu UKM Angkasa Timor, UKM Putri, UKM Yudhistira, UKM Citra Binoni, dan UKM Tambers. Metode pengumpulan data menggunakan metode survei yang dilaksanakan melalui observasi dan wawancara langsung dengan responden. Informasi yang diperoleh dari kumpulan data survei perusahaan sampel menggunakan kuesioner sebagai metode untuk mengumpulkan informasi primer (Singarimbun \& Effendi, 2006). Hal ini bertujuan untuk memperoleh gambaran mengenai produksi produk olahan se'i yang tersebar di seputaran Kota Kupang.

Selanjutnya dilakukan analisis Hayami yang merupakan metode perhitungan nilai dalam penelitian ini. Analisis dilakukan agar besarnya nilai tambah akibat proses produksi dari daging sapi menjadi se'i dapat diketahui. Penambahan atau perubahan nilai pada suatu produk karena produk tersebut telah diolah lagi selama produksi merupakan konsep dari nilai tambah (Coltrain et al., 2000). Peningkatan nilai pada produk yang dihasilkan akan meningkatkan keunggulan kompetitif suatu perusahaan (Felea \& Albăstroiu, 2013). Rumusan nilai tambah adalah Value Added $(\mathrm{VA})=$ Nilai Output - Nilai Input; sehingga nilai tambah bisa diperoleh melalui pengurangan nilai output dengan nilai input suatu produk. Adapun nilai tambah yang dihitung dengan analisis Hayami dapat diamati melalui Tabel 1.

Tabel 1. Perhitungan value added menggunakan analisis Hayami.

\begin{tabular}{|c|c|c|}
\hline No. & Variabel & Nilai \\
\hline \multicolumn{3}{|c|}{ Output, Input, dan Harga } \\
\hline 1. & Output (kg) & (a) \\
\hline 2. & Input Bahan Baku (kg) & (b) \\
\hline 3. & Input Tenaga Kerja (HOK) & (c) \\
\hline 4. & Faktor Konversi & $(\mathrm{d})=(\mathrm{a}) /(\mathrm{b})$ \\
\hline 5. & Koefisien TKL (HOK/kg) & $(\mathrm{e})=(\mathrm{c}) /(\mathrm{b})$ \\
\hline 6. & Harga Output (Rp/kg) & (f) \\
\hline 7. & Rata-rata upah tenaga kerja (Rp/HOK) & (g) \\
\hline \multicolumn{3}{|c|}{ Penerimaan dan Keuntungan (Rp/kg Bahan Baku) } \\
\hline 8. & Harga Input (Rp/kg) & (h) \\
\hline 9. & Sumbangan Input lain (Rp/kg) & (i) \\
\hline 10. & Nilai Output (Rp/kg) & $(j)=(d) \times(f)$ \\
\hline \multirow{2}{*}{11.} & Nilai Tambah $(\mathrm{Rp} / \mathrm{kg})$ & $(\mathrm{k})=(\mathrm{j})-(\mathrm{i})-(\mathrm{h})$ \\
\hline & Rasio Nilai Tambah & $(1)=(k) /(j)$ \\
\hline \multirow[t]{2}{*}{12.} & Pendapatan Tenaga Kerja & $(\mathrm{m})=(\mathrm{e}) \mathrm{x}(\mathrm{g})$ \\
\hline & Imbalan Tenaga Kerja & $(\mathrm{n})=(\mathrm{m}) /(\mathrm{k})$ \\
\hline \multirow[t]{2}{*}{13.} & Keuntungan & $(\mathrm{o})=(\mathrm{k})-(\mathrm{m})$ \\
\hline & Tingkat Keuntungan & $(\mathrm{p})=(\mathrm{o}) /(\mathrm{j})$ \\
\hline \multicolumn{3}{|c|}{ Balas Jasa Faktor Produksi (Rp/kg Bahan Baku) } \\
\hline \multirow[t]{4}{*}{14.} & Margin $(\mathrm{Rp} / \mathrm{kg})$ & $(q)=(j)-(h)$ \\
\hline & Pendapatan TKL (\%) & $(\mathrm{r})=(\mathrm{m}) /(\mathrm{q})$ \\
\hline & Sumbangan input lain (\%) & $(\mathrm{s})=(\mathrm{i}) /(\mathrm{q})$ \\
\hline & Keuntungan perusahaan (\%) & $(\mathrm{t})=(\mathrm{o}) /(\mathrm{q})$ \\
\hline
\end{tabular}

Sumber: Emhar et al., 2014. 


\section{Hasil dan Pembahasan}

\section{Komponen Biaya Produksi Se'i Sapi}

Komponen biaya produksi produk se'i sapi di Kota Kupang mempunyai perbedaan dibandingkan produk olahan daging sapi lainnya karena proses pengolahan serta kebutuhan bahan baku yang berbeda-beda pada masing-masing produk. Biaya pengadaan bahan utama meliputi $97,79 \%$ dari total biaya produk se’ $i$, biaya bahan penunjang mengambil porsi $0,17 \%$ total biaya, dan biaya lain mengambil porsi $2,04 \%$ dari total biaya.

Se'i merupakan daging asap khas Timor yang disukai hampir sebagian besar masyarakat NTT. Awal produksi se'i adalah dengan menggantung daging pada permukaan api dalam jarak tertentu. Proses pengasapan selama produksi se'i dilakukan untuk meningkatkan kualitas dan rasa daging. Se'i yang telah diproduksi merupakan daging yang tidak matang sempurna dan mempunyai daya simpan hingga 4 hari di suhu ruangan dan mampu bertahan hingga 4 minggu jika divakum. Daging segar yang digunakan untuk produk se’i merupakan daging yang berasal pada otot longissimus dorsi (leher, paha, perut, dan rusuk). Bahan baku dan peralatan pembuatan se'i tidak membutuhkan dana yang besar sehingga dapat diproduksi secara mandiri oleh masyarakat.

Tabel 2 menunjukkan bahwa biaya terbesar dalam produksi se'i adalah harga beli daging sapi sebesar Rp 6.300.000,00. Selanjutnya, penerimaan dan pendapatan yang diperoleh dari produk se'i berturut-turut senilai Rp 7.875.000,00 dan Rp 1.432.854,50.

Tabel 2. Struktur Biaya Pada Usaha Pengolahan Se’i di Kota Kupang, Tahun 2019

\begin{tabular}{|c|c|c|c|c|}
\hline Komponen Biaya & Satuan & Total & $\begin{array}{c}\text { Nilai } \\
\text { (Rp/produksi/pengusaha) }\end{array}$ & Persentase (\%) \\
\hline $\begin{array}{l}\text { Biaya Bahan Utama } \\
\text { Harga Beli Daging }\end{array}$ & $\mathrm{kg}$ & $70,00 \mathrm{~kg}$ & $6.300 .000,00$ & 97,80 \\
\hline $\begin{array}{l}\text { Biaya Bahan Penunjang } \\
\text { 1. Garam } \\
\text { 2. Kalium Nitrat } \\
\text { 3. Penyedap Makanan }\end{array}$ & $\begin{array}{l}\mathrm{kg} \\
\mathrm{kg} \\
\mathrm{kg}\end{array}$ & $\begin{array}{r}2,00 \mathrm{~kg} \\
0,00002 \mathrm{~kg} \\
0,00003 \mathrm{~kg}\end{array}$ & $\begin{array}{r}10.500,00 \\
115,50 \\
280,00 \\
\end{array}$ & $\begin{array}{r}0,20 \\
0,002 \\
0,004 \\
\end{array}$ \\
\hline $\begin{array}{l}\text { Biaya Tambahan } \\
\text { 1. Label dan Kemasan } \\
\text { 2. Kayu Api (Kesambi) }\end{array}$ & $\begin{array}{l}\mathrm{kg} \\
\text { Ikat }\end{array}$ & $\begin{array}{r}1,75 \mathrm{~kg} \\
4,00 \mathrm{ikat} \\
\end{array}$ & $\begin{array}{r}122.500,00 \\
8.750,00 \\
\end{array}$ & $\begin{array}{l}1,902 \\
0,092 \\
\end{array}$ \\
\hline $\begin{array}{l}\text { Total Biaya } \\
\text { Penerimaan } \\
\text { Pendapatan }\end{array}$ & & & $\begin{array}{l}6.442 .145,50 \\
7.875 .000,00 \\
1.432 .854,50 \\
\end{array}$ & 100,000 \\
\hline
\end{tabular}

Sumber: Diolah dari Data Primer, 2019.

\section{Nilai Tambah Pada Produk Se'i Sapi}

Pemberian nilai tambah pada bahan baku daging sapi dilakukan dengan pemrosesan daging sapi segar menjadi se'i. Nilai tambah didefinisikan sebagai selisih antara komoditas yang memperoleh perlakuan pada tahap tertentu dengan nilai korbanan yang digunakan selama berlangsungnya proses tersebut (Artika \& Marini, 2016). Perhitungan nilai tambah cenderung tidak sama pada setiap jenis usaha karena adanya perbedaan input dan perlakuan pada masing-masing usaha oleh setiap pelaku usaha (Marimin \& Maghfiroh, 2010). Tehnik analisis nilai tambah menggunakan Metode Hayami meliputi dua susunan biaya, yaitu biaya pemrosesan bahan baku dan pendapatan yang diperoleh dari produk yang telah dijual. Perhitungan nilai tambah usaha se'i sapi dapat diamati melalui Tabel 3.

Bahan baku daging segar untuk usaha se'i membutuhkan biaya dengan besaran Rp $90.000,00$ dengan jumlah kebutuhan daging $140 \mathrm{~kg}$. Berdasarkan penelitian, proses peningkatan nilai tambah dapat berjalan secara maksimal jika memperoleh tambahan dari input lainnya, yaitu sebesar Rp $1.895,27 / \mathrm{kg}$ dari total pemakaian input. Produk se'i yang telah dihasilkan memiliki harga $\mathrm{Rp} 110.700,00 / \mathrm{kg}$ dengan rasio nilai tambah sebesar $16,99 \%$ dari jumlah output; atau bernilai tambah Rp $18.804,73 / \mathrm{kg}$ dari se'i yang dihasilkan. Penerimaan pendapatan oleh pekerja mengambil porsi senilai Rp 5.938,81/ kg output atau memiliki rasio 31,58\% dari keseluruhan nilai tambah. Selanjutnya; perusahaan memperoleh laba Rp $12.865,92 / \mathrm{kg}$ se'i yang dihasilkan atau $11,62 \%$ dari keseluruhan output. Margin yang diperoleh pengusaha senilai Rp 20.700,00/kg se'i. Dari keseluruhan total margin, 62,15\% merupakan keuntungan perusahaan, pendapatan tenaga kerja mengambil 9,16\% dari total margin, dan $9,16 \%$ berupa sumbangan biaya bahan penunjang yang diperlukan selama proses pembuatan se'i. 
Tabel 3. Hasil Perhitungan Rata-Rata Value Added Produk Se’i di Kota Kupang dengan Analisis Hayami, Tahun 2019

\begin{tabular}{|c|c|}
\hline Struktur Penilaian & Besaran \\
\hline \multicolumn{2}{|l|}{ Output, Input, dan Harga } \\
\hline Output (kg) = (a) & 75,00 \\
\hline Input Bahan Baku (kg) = (b) & 140,00 \\
\hline Input Tenaga Kerja $(\mathrm{HOK})=(\mathrm{c})$ & 47,25 \\
\hline Faktor Konversi $=(\mathrm{d})=(\mathrm{a}) /(\mathrm{b})$ & 0,54 \\
\hline Koefisien TKL $(\mathrm{HOK} / \mathrm{kg})=(\mathrm{e})=(\mathrm{c}) /(\mathrm{b})$ & 0,34 \\
\hline Harga Output $(\mathrm{Rp} / \mathrm{kg})=(\mathrm{f})$ & $205.000,00$ \\
\hline Rata-Rata Upah Tenaga Kerja $(\mathrm{Rp} / \mathrm{HOK})=(\mathrm{g})$ & $17.467,10$ \\
\hline \multicolumn{2}{|l|}{ Penerimaan dan Keuntungan ( $R p / k g$ Bahan Baku) } \\
\hline Harga Input $(\mathrm{Rp} / \mathrm{kg})=(\mathrm{h})$ & $90.000,00$ \\
\hline \multicolumn{2}{|l|}{ Sumbangan Input Lain } \\
\hline Garam (Rp/kg) & 140,00 \\
\hline Penyedap Makanan (Rp/kg) & 3,73 \\
\hline Saltpeter & 1,54 \\
\hline Kemasan dan Label (Rp/kg) & $1.633,33$ \\
\hline Kayu Api (Kesambi) (Rp/kg) & 116,67 \\
\hline Total Biaya Lain $(\mathrm{Rp} / \mathrm{kg})=(\mathrm{i})$ & $1.895,27$ \\
\hline Nilai Output $(\mathrm{Rp} / \mathrm{kg})=(\mathrm{j})=(\mathrm{d}) \times(\mathrm{f})$ & $110.700,00$ \\
\hline Nilai Tambah $(\mathrm{Rp} / \mathrm{kg})=(\mathrm{k})=(\mathrm{j})-(\mathrm{i})-(\mathrm{h})$ & $18.804,73$ \\
\hline Rasio Nilai Tambah $(\%)=(1)=(\mathrm{k}) /(\mathrm{j})$ & $16,99 \%$ \\
\hline Pendapatan Tenaga Kerja $(\mathrm{Rp} / \mathrm{kg})=(\mathrm{m})=(\mathrm{e}) \mathrm{x}(\mathrm{g})$ & $5.938,81$ \\
\hline $\operatorname{Imbalan}$ Tenaga Kerja $(\%)=(\mathrm{n})=(\mathrm{m}) /(\mathrm{k})$ & $31,58 \%$ \\
\hline Keuntungan $=(\mathrm{o})=(\mathrm{k})-(\mathrm{m})$ & $12.865,92$ \\
\hline Tingkat Keuntungan $(\%)=(\mathrm{p})=(\mathrm{o}) /(\mathrm{j})$ & $11,62 \%$ \\
\hline \multicolumn{2}{|l|}{ Balas Jasa Faktor Produksi (Rp/kg Bahan Baku) } \\
\hline Margin $(\mathrm{Rp} / \mathrm{kg})=(\mathrm{q})=(\mathrm{j})-(\mathrm{h})$ & $20.700,00$ \\
\hline Pendapatan TKL $(\%)=(\mathrm{r})=(\mathrm{m}) /(\mathrm{q})$ & $28,69 \%$ \\
\hline Sumbangan Input Lain $(\%)=(\mathrm{s})=(\mathrm{i}) /(\mathrm{q})$ & $9,16 \%$ \\
\hline Keuntungan Perusahaan $(\%)=(\mathrm{t})=(\mathrm{o}) /(\mathrm{q})$ & $62,15 \%$ \\
\hline
\end{tabular}

Sumber: Diolah dari Data Primer, 2019

Jika dibandingkan dengan produk daging olahan asal Kota Kupang lainnya seperti abon sapi, dendeng sapi, dan se'i babi; produk-produk tersebut memiliki nilai tambah dan tingkat keuntungan yang lebih tinggi daripada produk se'i sapi. Hasil penelitian Kadju et al. (2020b) menunjukkan bahwa nilai tambah yang didapatkan oleh pelaku UKM di Kota Kupang dari produk abon mencapai Rp 32.807,27/kg dengan keuntungan perusahaan sebesar Rp 83,57\% dan produk dendeng mencapai Rp 29.757,67/kg dengan keuntungan perusahaan sebesar 85,65\%. Pada produk se'i babi, setiap 1 kilogram bahan daging babi segar yang digunakan dalam produksi se' $i$ babi memberikan nilai tambah sebesar Rp 34.397,00 dengan keuntungan perusahaan mencapai $75,35 \%$ dari keseluruhan margin yang diperoleh (Ina et al., 2016). Produk se'i sapi sendiri jika dibandingkan dengan produk lainnya memiliki nilai tambah yang rendah, yaitu sebesar Rp $18.804,73 / \mathrm{kg}$ dengan keuntungan perusahaan sebesar $62,15 \%$.

\section{Simpulan}

Kesimpulan berdasarkan hasil penelitian menunjukkan bahwa pengolahan se'i sapi oleh UMKM responden di wilayah Kota Kupang menghasilkan se'i rata-rata sebanyak 37,50 kg setiap harinya. Nilai tambah produk olahan se'i bernilai Rp $18.804,73 / \mathrm{kg}$ output yang dihasilkan dengan keuntungan mencapai Rp 12.865,92/ kg se'i.

\section{Pustaka}

Artika, I. B. E. \& Marini, I. A. K. 2016. Analisis Nilai Tambah (Value Added) Buah Pisang Menjadi Kripik Pisang di Kelurahan Babakan Kota Mataram (Studi Kasus Pada Industri Rumah Tangga Kripik Pisang Cakra). Ganec Swara, 10(1): 94-98.

Badan Pusat Statistik Indonesia. 2018. Statistik Indonesia 2018. Jakarta: BPS Indonesia.

Badan Pusat Statistik Kota Kupang. 2018. Kota Kupang Dalam Angka 2018. Kupang: BPS Kota Kupang.

Badan Pusat Statistik Provinsi Nusa Tenggara Timur. 2018. Provinsi Nusa Tenggara Timur Dalam Angka 2018. Kupang: BPS Provinsi NTT. 
Coltrain, D., Barton, D. \& Boland, M. 2000. Value Added: Opportunities And Strategies. Arthur Capper Cooperative Center, Department of Agricultural Economics. Kansas City (UK): Kansas State University.

Emhar, A., Murti, J., Aji, M. \& Agustina, T. 2014. Analisis rantai pasokan (supply chain) daging sapi di Kabupaten Jember. Berkala Ilmiah Pertanian, 1(33): 55-61.

Felea, M. \& Albăstroiu, I. 2013. Defining The Concept of Supply Chain Management and its Relevance to Romanian Academics and Practitioners. The Amfiteatru Economic Journal, 15(33): 74-88.

Ina, A. A. T., Luruk, M. Y. \& Keban, A. 2016. Analisis Nilai Tambah Daging Babi Segar Menjadi Se’i Babi Siap Saji (Studi Kasus Usaha Agroindustri Se’i Babi Di Baun). Jurnal Nukleus Peternakan, 3(2): 128-135. Retrieved from http: / / ejurnal.undana.ac.id/nukleus/article/view/798

Kadju, F. Y. D., Hartono, B. \& Nugroho, B. A. 2020a. Analysis of Beef Supply Chain in Kupang Town East Nusa Tenggara Province. IRJAES, 5(1): 69-73.

Kadju, F. Y. D., Hartono, B. \& Nugroho, B. A. 2020b. Analysis of Value Added on Entrepreneurship of Beef Shredded and Jerky in Kupang Town East Nusa Tenggara Province. IRJAES, 5(1): 222225.

Kusnandar, Mardikanto, T. \& Wibowo, A. 2010. Manajemen Agroindustri. Surakarta: Sebelas Maret University Press.

Marimin \& Maghfiroh, N. 2010. Aplikasi Teknis Pengambilan Keputusan dalam Manajemen Rantai Pasok. IPB Press.

Marsudi, H. 2013. Kajian Agroindustri Berbasis Masyarakat Kabupaten Karanganyar. Jurnal Riset Manajemen \& Akuntansi, 4(7): 21-44.

Noach, Y. R. \& Lalus, M. F. 2020. Analisis Indeks Koneksi Pasar dan Distribusi Margin Pada Lembaga-Lembaga Pemasaran Ternak Sapi Potong di Kabupaten Kupang Nusa Tenggara Timur Indonesia. Agrimor, 5(1): 13-16. https://doi.org/10.32938/ag.v5i1.939

Pasaribu, A. M. 2012. Kewirausahaan Berbasis Agribisnis. Yogyakarta: Andi.

Pusat Data dan Sistem Informasi Pertanian. 2017. Outlook Daging Sapi. Jakarta: Sekretariat Jenderal, Kementerian Pertanian.

Singarimbun, M. \& Effendi, S. 2006. Metode Penelitian Survei. Jakarta: LP3ES.

Soeparno. 2005. Mmu dan Teknologi Daging. 5 ed. Yogyakarta: Gadjah Mada University Press.

Suluh, D. G. 2019. Studi Perkembangan Kuman Pada Daging Se'i yang Dikemas Vakum dan Dikemas Tanpa Divakum. Oehonis: The Journal of Environmental Health Research, 3(1): 167174. 